\title{
социология
}

DOI: $10.17805 / g g z .2017 .1 .6$

\section{Культурный капитал семьи как условие формирования габитуса учащегося}

\author{
А. Н. Пинчук \\ МОСКОВСКИЙ ГУМАНИТАРНЫЙ УНИВЕРСИТЕТ
}

В статье рассматривается феномен образовательных практик в контексте непрерывного образования. Особое внимание автор обращает на культурный капитал семьи как первичные условия формирования габитуса учащегося. В аспекте межпоколенческого взаимодействия проблематизируется включенность информационных технологий в образовательные практики представителей старшего поколения, получивших советское образование. Ключевые слова: образовательные практики, габитус учащегося, культурный капитал, межпоколенческий аспект

\section{Family's cultural capital as condition for the formation of the habitus of the student}

\author{
A. N. PINCHUK \\ MOSCOW UNIVERSITY FOR THE HUMANITIES
}

The article considers the phenomenon of educational practices in the context of lifelong education. Special attention is drawn to the cultural capital of the family as the primary condition for the formation of the habitus of the student. In the aspect of intergenerational communication the role of information technologies in the educational practices of the older generation, who acquired Soviet education, is problematized.

Key words: educational practice, the student's habitus, cultural capital, intergenerational aspects

В 2015 г. в рамках Всемирного форума по вопросам образования в г. Инчхоне была принята Аекларация «Образование-2030: обеспечение всеобщего инклюзивного и справедливого качественного образования и обучения на протяжении всей жизни» (Аекларация..., 2015: Электр. ресурс). Провозглашая образование «общественным благом», Инчхонская декларация, утверждает принцип «...качественного обучения на протяжении всей жизни для всех, во всех структурах и на всех уровнях образования» (там же). Тем самым, мировое образовательное сообщество определило концепцию будущего развития образования, построенную на принципах равного доступа, качества и непрерывности. Но за принципом «образование длиною в жизнь» следует важный вопрос - как будет учиться индивид на протяжении всей своей жизни? И здесь необходимо обратиться к опривыченной форме действия, к социальным практикам индивида. Социальные практики, сконструированные в образовательном пространстве, отражает феномен образовательных практик. Таким образом, образовательные практики репрезентируют опривыченные способы приобретения, усвоения новых знаний, умений, навыков, типизированные приемы нахождения информации. Аля образовательных практик характерна массовость, типичность, воспроизводимость. Как и другие социальные практики, образовательные практики можно зарегистрировать, зафиксировать, но, необходимо помнить, что знание о практиках, как писали В. В. Вол- 
ков и О. В. Хархордин, это «знание «как», а не знание «что» (Волков, Хархордин, 2008: 42).

Порождающим механизмом образовательных практик выступает габитус учащегося. В контексте непрерывной системы образования можно рассмотреть габитус школьника, студента, взрослого обучающегося. Поэтапное прохождение ступеней образования отражает условия формирования габитуса, который не допускает «...ни создания чего-либо невиданно нового, ни простого механического воспроизводства изначально заданного» (Бурдье, 2001: 108). П. Бурдье пишет о том, что: «...нельзя вывести практики ни из имеющихся в настоящее время условий, которые, как может показаться, порождают данные практики, ни из прошлых условий, которые произвели габитус, устойчивый принцип их производства» (Бурдье, 2001: 109). Поэтому при изучении образовательных практик важно соотнесение социальных условий конструирования габитуса учащегося с теми условиями, в которых он «был приведен в действие» (там же: 110).

В формировании габитуса можно отметить хронологическую упорядоченность. Указывая на это, Н. А. Шматко (Шматко, 1998) выделяет первичный и вторичный габитус. По мнению автора «первичный габитус, сложившийся в семье, служит основой восприятия и усвоения школьного образования; вторичный (школьный) габитус выступает условием и предпосылкой восприятия и оценивания сообщений СМИ и т. А.» (там же: 65). Следовательно «первичный» габитус в сфере образования прежде всего формируется в семье в процессе социализации индивида. В этой связи особую значимость приобретает культурный капитал семьи, который обязательно необходимо учитывать при исследовании образовательных практик.

Теорию культурного капитала также развивал П. Бурдье. Согласно позиции французского ученого, существуют три состояния культурного капитала. Первое из них, инкорпорированное, когда культурный капитал выступает в форме знаний и диспозиций тела. «Накопление культурного капитала в инкорпорированном состоянии, т. е. в форме того, что называется культурой, культивированием [Bilding], предполагает процесс воплощения в телесные формы [em-bodiment], инкорпорирования» (Бурдье, 2002: 61, Электр. ресурс). Инкорпорированный культурный капитал, являясь неотъемлемой частью габитуса, может быть приобретен в различном объеме в зависимости от времени, социокультурных условий, социального класса, к которому принадлежит индивид. Важно учитывать, что культурный капитал в больше мере выступает как символический капитал, когда он остается не признанным в качестве капитала, а признается «...в качестве легитимной компетенции, в виде силы, влияющей на узнавание (или неузнавание)» (там же: 62). Соответственно символическое различение может приносить обладателям дефицитного культурного капитала материальную и символическую прибыль.

При анализе накопления культурного капитала агентом необходимо обратить внимание на полученное домашнее образование и инкорпорированный культурный капитал семьи. Здесь работает обобщенный эффект Эрроу, который, как объясняет П. Бурдье, «...фиксирует тот факт, что все культурные блага (картины, памятники, машины и любые предметы, созданные руками человека, в особенности те, что связаны с миром детства) оказывают обучающее воздействие самим своим существованием» (там же: 62-63). При этом наиболее легкое и быстрое накопление и присвоение культурного капитала происходит, как правило, в тех семьях, которые уже обладают достаточно мощным культурным капиталом. 
Исходя из того, что разные семьи имеют различный культурный капитал, можно сделать вывод о различных возможностях приобретения определенного уровня образования агентом, проходящим социализацию в той или иной семье. Так, продолжительность времени, в течение которого индивид может приобрести культурный капитал, лимитируется свободным временем от необходимости начинать трудовую карьеру, которое способна обеспечить ему семья (там же).

Помимо инкорпорированного, в культурном капитале можно выделить и объективированное его состояние, представленное культурными товарами, предметами, и другими материальными вещами. Также можно рассмотреть и институционализированное состояние культурного капитала, когда он выступает в виде академических квалификаций, формально подтвержденных компетенций. В этом случае культурный капитал юридически закреплен, что делает данную форму капитала «относительно независимой от своего владельца и даже от самого культурного капитала» (там же: 65).

На сегодняшний день уже встречаются работы, в которых представлен опыт измерения культурного капитала на эмпирическом уровне (Большаков, 2013; Рощина, 2012). Например, Н. В. Большаков (Большаков, 2013) проводит анализ каждого состояния капитала через следующие переменные. В институционализированном состоянии автор выделяет уровень образования, ученую степень, наличие публикаций, престижность полученного образования. В объективированном состоянии культурного капитала ученый фиксирует частоту посещения музеев, выставок, наличие предметов искусства дома, субъективную оценку количества книг и другое. В инкорпорированной форме культурного капитала ученый отмечает языковую компетенцию, характеристики среды, в которой проходила социализация, в том числе уровень образования родителей, место жительства во время обучения в школе и т. А. (Большаков, 2013: 8).

Я. М. Рощина (Рощина, 2012) осуществила попытку изучить семейный капитал как фактор образовательных возможностей школьников. Примечательно, что в качестве независимых переменных объема семейного капитала, Я. М. Рощина выделяет материальный, человеческий, социальный капитал и культурный капитал, представленный, в данном случае, семейной библиотекой. Если кратко резюмировать выводы автора, то результаты социологического исследования показали зависимость между объемом семейного капитала и образовательными возможностями школьников, однако выявленное влияние, как констатирует ученый, «...сильнее проявляется в уже имеющихся достижениях и инвестициях в человеческий капитал» (Рощина, 2012: 269).

То, что различная подготовка, которая отражается в объеме накопленного культурного капитала, проявляется в дальнейших траекториях в образовании подтверждается и другими исследованиями. Например, Константиновский А.. ., Вознесенская Е. А., Чередниченко Г. А. (Константиновский, Вознесенская, Чередниченко, 2014) отмечают особую роль стартового образовательного ресурса при выстраивании Аальнейших образовательных и профессиональных траекторий и накоплении человеческого капитала. Изначально ученые зафиксировали за тремя группами молодежи разные типы стартового образования, которые обозначают как: «..бывших выпускников средних школ», соответственно поток «школа», «бывших выпускников ССУЗов»«поток ССУЗ», «бывших выпускников ПУ»- «поток ПУ» (там же: 63). «Уже в год получения «стартового» образования (школа, ССУЗ, ПУ) - в 1998 г. обнаружилось 
основное различие между потоками «ССУЗ» и «ПУ»: юноши и девушки первого потока практически полностью $(95,6 \%)$ продолжают обучение, причем большинство в вузах $(65,8 \%)$, а вторые и третьи во многом чаще сохраняют уровень полученного начального или среднего профессионального образования» (там же: 64).

Таким образом, культурный капитал семьи является важным фактором формирования габитуса в сфере образования, который важно и нужно учитывать при изучении образовательных практик. В частности, можно рассмотреть уровень образования родителей учащихся, частоту посещения культурных, образовательных и иных мероприятий в детстве, особенности духовного и материального потребления семьи, участие в домашнем обучении детей родителей или представителей более старшего поколения, их образовательные практики, способы обучения, уровень материального обеспечения, предметы обстановки домашнего обучения, образовательные материалы, с помощью которых осуществляется учебный процесс дома (книги, компьютер, гаджеты и т. А.).

Необходимо отметить, что в последнее время особую значимость приобретает включение в образовательные практики информационных технологий. В этой связи, следует отдельно рассмотреть аспект межпоколенческого взаимодействия. Представители старшего поколения обучались в советской системе образования без использования цифровых технологий, однако на данный момент они находятся в условиях массовой компьютеризации, когда невозможно представить организацию учебного процесса без современной техники. В раннем возрасте дети усваивают практики, распространенные в семье. Понимание того, какие образовательные практики характерны для обучающих их родственников взрослых, в какой мере используются ими электронные средства связи в учебных целях, какие практики остались неизменными от советского прошлого, с одной стороны, поможет более подробно охарактеризовать культурный капитал семьи, как условие формирования габитуса современных школьников, студентов. С другой, позволит рассмотреть то, как со временем изменились образовательные практики в свете произошедшей информатизации образовательного пространства, проанализировать возможный разрыв поколений. Более того, сегодня, когда общепризнанным стал принцип непрерывного образования, важно изучить и то, как он действительно реализуется в жизни старшего поколения, которые начинали учиться в то время, когда книга и преподаватель были основными источниками знаний, а продолжают - в эпоху новых технологий и Интернета.

Итак, подводя итог вышеизложенному, отметим, что особенности образовательных практик во многом опосредованы первоначальными условиями своего конструирования. Тем самым их исследование необходимо проводить не только с учетом контекста воспроизводства в текущий момент времени, но и посредством анализа условий изначального формирования. Особую роль в конструировании первичного габитуса учащегося играет культурный капитал семьи. В рамках межгенерационного взаимодействия можно рассмотреть спектр образовательных практик, опосредованных габитусом учащегося советской и современной системы образования, как представителей различных эпох. И текущий исторический период предоставляет такую уникальную возможность.

\section{СПИСОК АИТЕРАТУРЫ}

Бурдье, П. (2001) Практический смысл / пер. с фр. СПб. : Алетейя; М. : Ин-т эксперимент. социологии. $562 \mathrm{c.}$ 
Бурдье, П. (2002) Формы капитала [Электронный ресурс] // Экономическая социология. Электронный журнал. №5. Т. 3. С. 60-74. https://ecsoc.hse.ru/data/2011/12/08/1208205039/ ecsoc_t3_n5.pdf (дата обращения 29.11.2016).

Волков, В. В., Хархордин, О. В. (2008) Теория практик. СПб. : ИзА-во Европейского ун-та в Санкт-Петербурге. 298 с.

Аекларация «Образование-2030: обеспечение всеобщего инклюзивного и справедливого качественного образования и обучения на протяжении всей жизни» [Электронный ресурс] // http://unesdoc.unesco.org/images/0023/002331/233137r.pdf (дата обращения 29.11.2016).

Константиновский, А. А., Вознесенская, Е. А., Чередниченко, Г. А. (2014) Молодежь России на рубеже XX-XXI веков: образование, труд, социальное самочувствие. М. : ЦСП и М. 548 с.

Рощина, Я. М. (2012) Семейный капитал как фактор образовательных возможностей российских школьников // Вопросы образования. № 1. С. 257-277.

Шматко, Н. А. (1998) «Габитус» в структуре социологической теории // Журнал социологии и социальной антропологии. № 2. Т. 1. С. 60-70.

Дата обращения: 07.01.2017 г.

Пинчук Антонина Николаевна - аспирант кафедры социологии Московского гуманитарного университета. Адрес: 111395, Россия, г. Москва, ул. Юности, д. 5. Тел.: +7 (499) 374-60-21. Эл. адрес: antonina.pinchuk27@bk.ru. Научный руководитель - A-р. социол. наук, проф. Селиверстова Н. А.

Pinchuk Antonina Nikolaevna, Postgraduate Student, Department of Sociology, Moscow University for the Humanities. Postal address: 5 Yunosti St., Moscow, Russian Federation, 111395. Tel.: +7 (499) 374-60-21. E-mail: antonina.pinchuk27@bk.ru. Research advisor: N. A. Seliverstova, Doctor of Sociology, Professor.

\section{Аля иитирования:}

Пинчук А. Н. Культурный капитал семьи как условие формирования габитуса учащегося [Электронный ресурс] // Горизонты гуманитарного знания. 2017, № 1. URL: http://journals. mosgu.ru/ggz/article/view/444 (дата обращения: дА.мм.гггг.). DOI: 10.17805/ggz.2017.1.6 